\title{
Value Creation through Acquisition Strategy: A Study of Volvo's Acquisition by Geely
}

\author{
Yane Chandera*, Handyanto Widjojo** \\ Prasetiya Mulya Business School, Jakarta - Indonesia
}

\begin{tabular}{|c|c|}
\hline ARTICLE INFO & A B S T RACT \\
\hline $\begin{array}{l}\text { Received: December 16, } 2011 \\
\text { Final revision: May 3, } 2012\end{array}$ & $\begin{array}{l}\text { This paper examines the value creation on the acquisition of Volvo } \\
\text { Car Corp by Zheiiang Geely Holding Group. The acquisition of Volvo }\end{array}$ \\
\hline $\begin{array}{l}\text { Keywords: } \\
\text { value creation, } \\
\text { acquisition, } \\
\text { Geely, } \\
\text { Volvo, } \\
\text { automotive, } \\
\text { China, } \\
\text { event study, } \\
\text { abnormal return, } \\
\text { cumulative abnormal return, } \\
\text { management, } \\
\text { brand perception, } \\
\text { cross border transaction }\end{array}$ & $\begin{array}{l}\text { by Geely became an interesting topic to discuss since it was the first } \\
\text { time in automotive industry that a Chinese company acquired an } \\
\text { international company with a considerably high transaction amount. } \\
\text { The paper examines the short term value creation using event study } \\
\text { to calculate abnormal returns of each company's stock during } \\
\text { the announcement period and measuring the significance of the } \\
\text { cumulative abnormal return. The findings are consistent with previous } \\
\text { studies over the years which have shown that most acquisitions fail } \\
\text { to add value for shareholders in the acquiring company. The paper } \\
\text { discusses the broad managerial implications of the findings this paper } \\
\text { discussion on marketing aspect after the acquisition by integrating two } \\
\text { different brand perceptions. }\end{array}$ \\
\hline
\end{tabular}

Corresponding author:

ychandera@pmbs.ac.id

**handy@pmbs.ac.id

(C) 2012 IRJBS, All rights reserved.

$\mathrm{A}$ utomotive industry in China has been growing tremendously for the last some years (China Association of Automobile Manufacturer, 2009; Ma, Pagán, \& Chu, 2009), since it became the member of World Trade Organization and was more exposed to open market mechanism (World Trade Organization, 2001). Considering the increase of fierce global competition and the slowdown of the global economy, Chinese government decided to revitalize the automotive industry. Acquisition strategy was one of the Chinese government strategy to speed up China auto industry to become the big 10 internationally auto manufacturer as well as to attract more international capital (Harlem \& Scramm, 2009).

The prerequisite of the successful merger and acquisition (M\&A) as the vehicle for improving 
share holder value (Birch, 1988) has been carried on. The previous research findings in M\&A still showed indecisive conclusion. Several case got successful results (Jensen \& Ruback, 1983, Bradley, Desai \& Kim, 1988; Kang \& Takeshi, 1996; Kang, Shivdasani \& Yamada, 2000; Jensen, 2006; Croci, 2006; Soongswang, 2010), while the others experienced unsuccessful value creation (Campa \& Hernando, 2004; Bhagat \& Hirshleifer, 1996; Black, Carnes, \& Jandik, 2001). In automotive industry, M\&A has occurred in the merger of Renault-Nissan and acquisition of Ford to Volvo (Donnelly, Morri and Donnelly, 2005; Lundbäck and Hörte, 2005) The study on the effect of merger of Renault-Nissan and the acquisition of Volvo by Ford showed that carefully thought should be worked out to emerge the value creation post merger implementation. Based on a sample of 230 takeover announcements between 1981 and 2007 in the automotive supply industry, significant positive announcement returns to acquiring companies were determined, bu acquirers were unable to sustain this exceptional position beyond a short-term horizon (Laabs \& Schiereck, 2010)

In March 2010, Zhejiang Geely Holding Group (hereinafter referred to as "Geely"), the parent of Geely Automobile purchased Volvo Car Corp (hereinafter referred to as "Volvo") from Ford Motor for about $\$ 1.50$ billion excluding debt. The acquisition of Volvo by Geely become an interesting topic to discuss since it happened for the first time in automotive industry that a Chinese company did the acquisition toward an internationa company in a considerably high transaction amount. Some researches in automotive industry tried to project the future result post acquisition implementation from different views, such as style of the management (Platt, 2010), human resource impact to product development (Dolan \& Shirouzu, 2009), and implementation of global strategy (Dolan \& Shirouzu, 2010). However, the research examining on short term value creation has no been conducted. The research become importan since it can predict the long-term performance of a deal (McWilliams \& Siegel, 1997), test the initial actions, anticipate the near future result and consider the future strategy. The event study method is a powerful tool in assessing the financial impact of corporate policy changes without the need to analyze accounting-based measures of profit which often subject to manipulation by insiders (McWilliams \& Siegel, 1997). Accordingly, the measurement of stock price changes around the announcement of Volvo's acquisition by Geely should reflect the discounted value of all future cash flows from each firm and incorporate all relevant information. This research examined the short term value creation through Volvo's acquisition by Geely and the findings will be mainly discussed from marketing view.

\section{Literature Review}

Given rationality in the stock market, the effects of an event such as mergers and acquisitions on the value of firms are measured by the construction of security prices observed over a short term period (MacKinlay, 1997). After the first published study (James Dolley, 1933), the level of sophistication of event studies had increased and improved including the removal general stock market price movements and separating confounding events (Eugene Fama et al. (1969).

Value creation for acquiring firms in the existing mergers and acquisitions had been inconclusive (Andrade, Mitchell, \& Stafford, 2001; King, Dalton, Daily, \& Covin, 2004; Moeller \& Schlingemann, 2005; Seth, Song, \& Pettit, 2002). Some surveys show significant positive returns on acquisition process (Bradley, Desai \& Kim, 1988; Jensen, 2006; Soongswang, 2010) following the earlier study that indicates the acquiring firm get statistically significant positive return from $2.40 \%$ to $6.70 \%$ and the weighted average returns of $3.8 \%$ (Jensen \& Ruback, 1983). The positive but insignificant abnormal returns have been observed in Japanese firms (Pettway \& Yamada, 1986). Some Japanese studies find that the bidding firms gain significantly positive two-day abnormal returns of $1.20 \%$ and
1.41\%, respectively (Kang and Yamada, 1996; Kang, Shivdasani \& Yamada, 2000). A study indicates that successful managers or acquirers tend to make a series of acquisitions and show persistent success indicated by the cumulative abnormal return that can approach $0.80 \%$ around the announcement date (Croci, 2006).

On the opposite side, Campa and Hernando find that ten out of seventeen studies on mergers and acquisitions report significantly negative abnormal returns which vary between less than $1 \%$ and $-5 \%$ (Campa and Hernando, 2004). The bidders on average pay too much for targets in cash tender offer cases (Bhagat and Hirshleifer, 1996). Other studies also show no gain or negative result in merger and acquisition (Jensen and Ruback, 1983; Bradley, Desai, \& Kim, 1988; Morck et al., 1990; Gaughan, 2005, and Morellec, 2008)

Evidence on international acquisitions as a valueaccretive strategy so far also has been mixed and inconclusive (Reuer, Shenkar, \& Ragozzino, 2004; Seth, Song, Pettit, 2002; Shimizu et al., 2004; Tuch \& O'Sullivan, 2007). A study of UK cross-border public acquisitions, the announcement result in zero short term returns and negative post-acquisition returns (Conn, Cosh, Guest, \& Hughes, 2005). A study of sample of 4430 acquisitions between 1985 and 1995 after controlling for various factors found that US firms who acquire cross-border targets experience a lower announcement stock returns. (Moeller \& Schlingemann, 2005)

On the opposite site, after examining all "completed" cross-border acquisitions made by publicly traded Indian firms, from January 2000 to December 2007, it was observed that overseas acquisition by Indian firms result in value creation to the acquirer. (Gubbi et al., 2010). International markets logically serve as learning laboratories (Hitt, Hoskisson, \& Kim., 1997) and act as channels that provide access to diverse, locally embedded ideas and knowledgebased capabilities from across the world (Almeida, 1996; Chang, 1995; Doz, Santos, \& Williamson,
2001). There is a motivation of the recent "second wave" internationalization of firms from developin economies to acquire strategic assets and to learn in addition to exploiting their stock of firmspecific advantages (Makino, Lau, Yeh, 2002). In cross-border acquisitions, the potential to acquire resources and capabilities in international markets to develop new advantages has been the pulling factor besides the pushing factor of firm-specific advantages. (Shan \& Song, 1997).

Again, although Volvo acquisition by Geely migh be part of a second wave of internationalization of emerging firms which is forced by several insights from existing literature such as "in dynamic environments, acquisitions may reduce bounded rationality and time compression diseconomies ... [and] provide the opportunity for the transfer of resources, capabilities, and personnel with critical experience between organizations." (Uhlenbruck, Hitt, Semadeni, 2006), this case is unique and under researched. The optimistic result found in the case of Indian firms might not apply to Chinese firms. "Although our study shows the value-creating potential of international acquisitions for emergingeconomy firms, these findings should be considered preliminary, given the narrow methodological and contextual scope of the paper; our contentions are based on the initial evidence available on crossborder acquisitions by firms from a single country (read: India) and from the expectations of the stock market to these acquisitions." (Gubbi et al, 2010).

According to Datta and Puia, cross border merger and acquisitions did not create significant value to the acquirers (Datta and Puia, 1995). However, in the short term, the impact of cross border mergers and acquisitions has been positive for the targe firms (Datta, Pinches, Narayanan, 1992; Harris and Ravenscraft, 1991; Andrade, Mitchell \& Stafford, 2001; Brimble and Sherman, 1999; Otchere \& Ip 2006)

Consistent with general literature, it would be interesting to know whether the acquisition of Volvo 
by Geely would create a negative short term value creation for Geely and positive short term value creation for Volvo. Furthermore, the discussion will follow the traditional western approach on the importance of the fit between the firm and its environment as well as the resource-based view (Vu, Shi, \& Hanby, 2009).

\section{METHODS}

Estimating CAR Using Single-factor (Market) Mode

The Ex Ante Market Reaction is analyzed to measure market reaction to the initial merger announcement in the form of the significance of cumulative abnormal return of both the acquiring and the acquired share prices (Copeland, Koller, \& Murrin, 1996).

To evaluate the impact of this acquisition announcement on each company's share prices, the CAR (Cumulative Abnormal Returns) is calculated around the event window period (-30 to 30 days). This CAR analysis represents markets' expectation of the costs and benefits of the proposed merge and the probability that the deal will go through In this case, the analysis attempts to determine whether the market perceives the action will create or destroy value of either firm's shareholders.

Fama, et. al. (1969) market model assumes that all interrelationships among the returns on individua asset arise from a common market factor that affects the return on all assets. The following mode is used to evaluate the significance of value creation:

$$
R_{t}=\alpha+\beta * R_{m t}+e_{t}
$$

With $\mathrm{E}\left(\mathrm{e}_{\mathrm{t}}\right)=0$ and $\operatorname{Var}\left(\mathrm{e}_{\mathrm{t}}\right)=\sigma^{2} \mathrm{e}$

Where

$\mathrm{R}_{\mathrm{t}}=$ actual returns at time $\mathrm{t}$

$\alpha=$ Ordinary Least Squares estimate of the intercept of the market model from a regression over the clean perio

$\beta=$ Ordinary Least Squares estimate of the market model slope coefficient reflecting change in the market return relative to the stock return

$\mathrm{R}_{\mathrm{mt}}=$ actual returns to a market portfolio

$\mathrm{e} \quad=$ residual

After the values of $\alpha$ and $\beta$ are estimated, the abnormal return at a time t during the period around the acquisition announcement date is defined as:

$$
A R_{t}=R_{t}-\left(\alpha+\beta * R_{m t}\right)
$$

The cumulative or aggregated abnormal returns of Geely and Volvo within the event window $\left(\mathrm{t}_{1}, \mathrm{t}_{2}\right)$ can be measured individually as:

$$
\operatorname{CAR}\left(\mathrm{t}_{1}, \mathrm{t}_{2}\right)=\sum_{t=t l}^{t=t 2} \text { ARt }
$$

A procedure similar to that of Dodd and Warner (1983) is then conducted to examine the statistical significance of the standardized cumulative residual between any two dates (Dodd \& Warner, 1983). For each security $\mathrm{j}$, the prediction error PEjt for each of the $\left(d_{2 i}-d_{1 i}+1\right)$ days in the period under study $\left(\mathrm{t}=\mathrm{d}_{\mathrm{i},}, \mathrm{d}_{\mathrm{ii}}+1, \ldots, \mathrm{d}_{2}\right)$ is standardized by the square root of its estimated forecast variance, to form a standardized prediction error, $\mathrm{SPE}_{\mathrm{j}}$,

$$
\mathrm{SPE}_{\mathrm{jt}}=\mathrm{PE}_{\mathrm{jl}} / \mathrm{s}_{\mathrm{jt}}
$$

Where
$s_{\mathrm{jt}}=\left\{s_{j}^{2}\left(1+\frac{1}{L_{j}}+\frac{\left(\mathrm{R}_{\mathrm{mt}}-\overline{\mathrm{R}}_{\mathrm{m}}\right)^{2}}{\sum_{\mathrm{l}=1}^{L}\left(\mathrm{R}_{\mathrm{mt}}-\overline{\mathrm{R}}_{\mathrm{m}}\right)^{2}}\right)\right\}^{\frac{1}{2}}, L_{j} \leq 300$

$s_{\jmath}^{2}$ is the estimated residual variance from the market model regression for security j. $\bar{R}_{m}$ is the average market return over the $L_{i}$ days used for the regression, and $\mathrm{R}_{\mathrm{mt}}$ is the return to the market index at day $t$.

The standardized prediction errors for each of the $\left(d_{2 j}-d_{1 j}+1\right)$ days of the prediction interval under study are summed for each security $\mathrm{j}$ to form a standardized cumulative prediction error $\mathrm{W}_{\mathrm{j}}$,

$$
W_{j}=\sum_{j=\mathrm{d}_{\mathrm{n}}}^{t=\mathrm{d}_{y_{j}}} \mathrm{SPE}_{\mathrm{ji}} \frac{1}{\sqrt{\mathrm{d}_{2 \mathrm{j}}-\mathrm{d}_{\mathrm{lj}}+1}}
$$

According to Dodd and Warner, if the prediction errors PEjt are normal and independent across t, then the standardized cumulative prediction error is distributed Student-t with degrees of freedom; since is large, is assumed to be distributed unit normal.

The significance of the average standardized cumulative prediction error in a sample of $\mathrm{N}$ securities can be computed as follows:

$$
Z=\bar{W}_{j} \sqrt{N}
$$

Where

$\bar{W}_{j}=\frac{1}{N} \sum_{j=1}^{N} W_{j}$

Again, if it is assumed that the standardized cumulative prediction errors are independent across securities, then if the expected value of the standardized prediction error is equal to 0 , the $\mathrm{Z}$ distribution is normal for the assumed unit normal $W_{i}$ 's.

In the analysis of acquisition of Volvo by Geely, each firm's share returns are observed individually instead of as a one portfolio. Therefore $\mathrm{j}$ and $\mathrm{N}$ are equal to 1 .

The expected value of CAR is zero in the absence of an event and thus the hypotheses are:

$$
\text { H1: } C A R_{\text {Geely }}\left(t_{1}, t_{2}\right)<0
$$

H2: $\operatorname{CAR}_{\mathrm{VavoO}}\left(t_{t}, t_{2}\right)>0$

\section{Event definition and date of announcemen}

The event date is defined as the first date of media announcement of the merger (day zero) which is March 29, 2010.

"The board of directors (the "Board") of the Company announces that it has been advised by the
Zhejiang Geely Holding Group Company Limited ("Geely Holding"), a company owned as to $90 \%$ by Mr. Li Shu Fu ("Mr. Li"), an executive director and the controlling shareholder of the Company, that it has on 28 March 2010 entered into a formal sale and purchase agreement with Ford Motor Company pursuant to which Geely Holding has agreed to purchase the entire issued share capital of Volvo Car Corporation (the "Geely Holding Acquisition"). The Geely Holding Acquisition is subject to completion which is expected to take place in September 2010." (Geely, 2011)

Geely Window Period and Clean Period Data. The event or window period has been taken from -30 days to the date of announcement to 30 days which are from February 15, 2010 to May 12, 2010. The clean period data for Geely as the acquirer has been taken as 222 days before the window period which are from March 25, 2009 to February 11, 2010.

The share price data for Geely which is GEEL AUTO/ (175) and the market index data which is HANG SENG INDEX ( $`$ HSI) have been taken from finance.yahoo.com.

Volvo Window Period and Clean Period Data. The event or window period has been taken from -30 days to the date of announcement to 30 days which are from Feb 15, 2010 to May 12, 2010. The clean period data for Volvo as the target firm has been taken as 222 days before the window period as well which are from March 25, 2009 to February 11, 2010. The share price data for Volvo which is VOLV B and the market index data which is OMXN40 INDEX (OMXN40.ST) have been taken from finance.yahoo. com.

\section{RESULTS AND DISCUSSION}

On Geely side, the pattern of CAR shows the apparently unfavorable market reaction during the announcement period. However, the pattern of Volvo's CAR shows the apparently favorable marke reaction during the announcement period. These results are consistent with the results of most of 


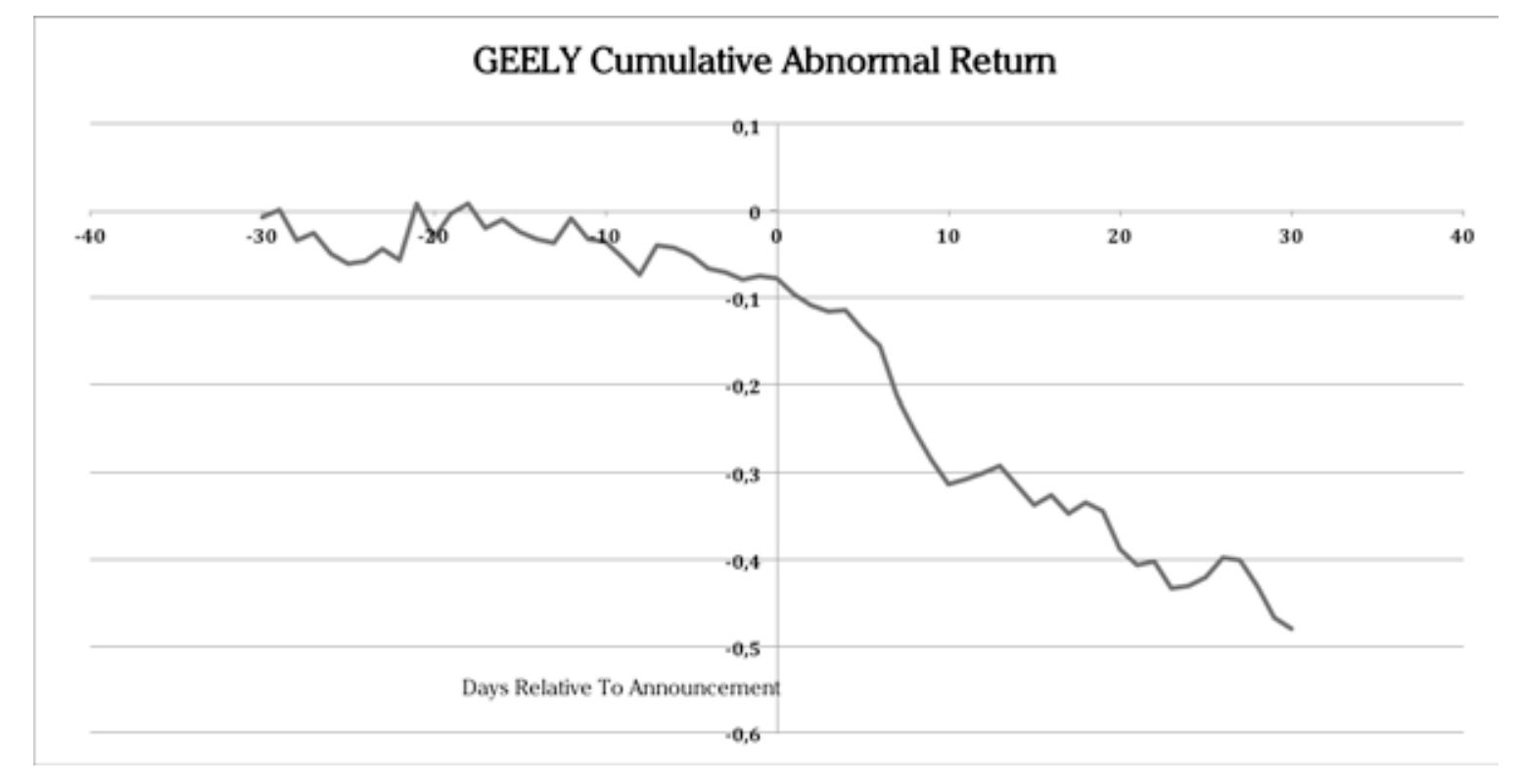

Figure 1. Geely's cumulative abnormal returns around merger announcements.

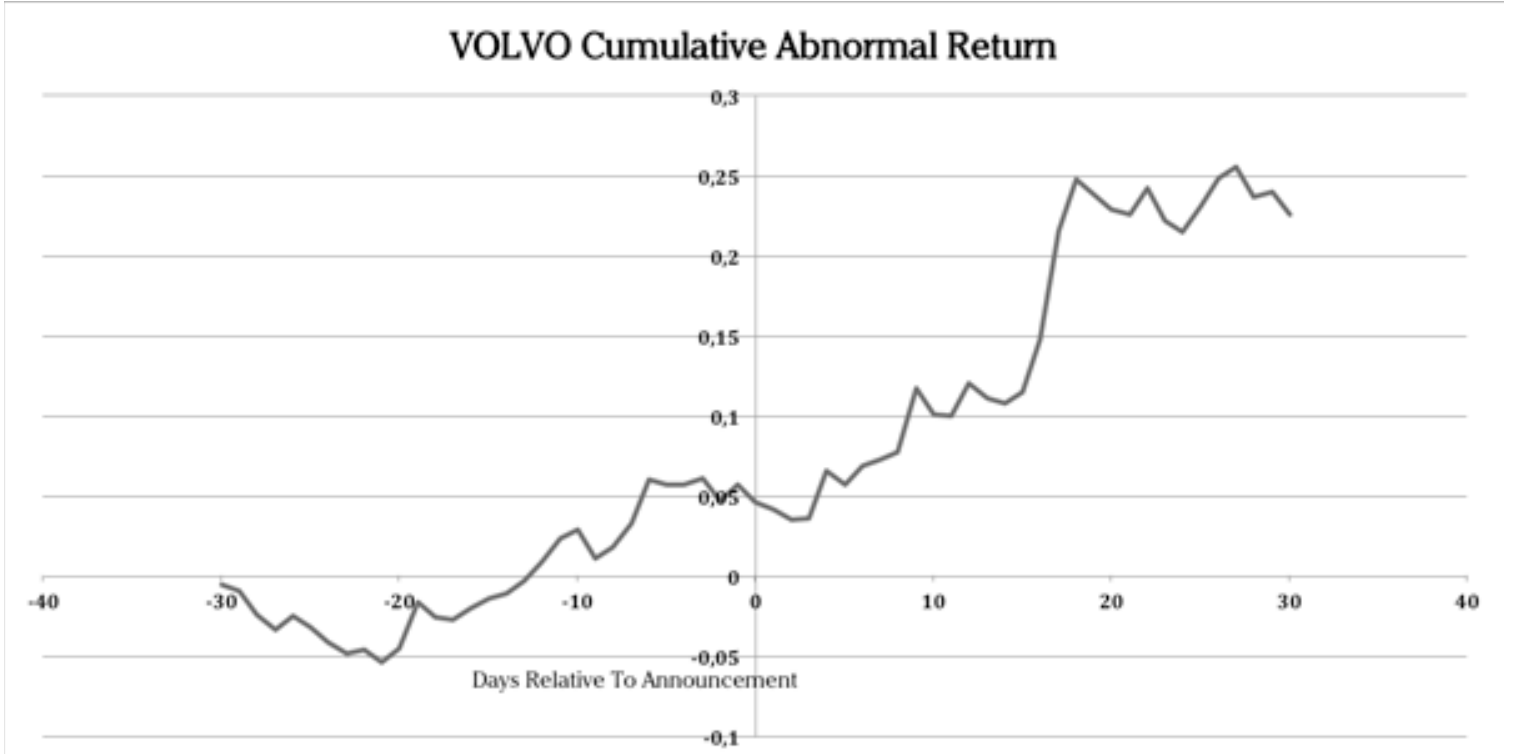

Figure 2. Volvo's cumulative abnormal returns around merger announcements.

the previous studies that successful targets realize gains whereas the studies disagreed on the effect of mergers on the stock prices of acquirers. Findings on significant negative abnormal performance for the acquirers which is consistent with the result of this particular study has been reported (Dodd \& Warner, 1983).
The statistical test suggests that for Geely, the acquisition announcement can be associated with weak negative cumulative abnormal return from the period of $(-30,-30)$ days until the period of $(-30,15)$ days of acquisition period. Furthermore from the period of $(-30,15)$ days until the period of $(-30,30)$ days of acquisition period there appears to be
Tabel 1. Table 1. Daily Abnormal Returns for Geely from 11 February 2010 to May 13,2010 in percent

\begin{tabular}{lcccc}
\hline Date & ARt $=$ Rt-E(Rt) & & Date & ARt= Rt-E(Rt) \\
\cline { 1 - 2 } \cline { 5 - 5 } $2 / 11 / 2010$ & $-0.66 \%$ & & $4 / 20 / 2010$ & $0.92 \%$ \\
$2 / 12 / 2010$ & $0.91 \%$ & & $4 / 21 / 2010$ & $-2.29 \%$ \\
$2 / 17 / 2010$ & $-3.52 \%$ & & $4 / 22 / 2010$ & $-2.31 \%$ \\
$2 / 18 / 2010$ & $0.78 \%$ & & $4 / 23 / 2010$ & $1.21 \%$ \\
$2 / 19 / 2010$ & $-2.35 \%$ & & $4 / 26 / 2010$ & $-2.13 \%$ \\
$2 / 22 / 2010$ & $-1.17 \%$ & & $4 / 27 / 2010$ & $1.15 \%$ \\
$2 / 23 / 2010$ & $0.24 \%$ & & $4 / 28 / 2010$ & $-0.86 \%$ \\
$2 / 24 / 2010$ & $1.53 \%$ & & $4 / 29 / 2010$ & $-4.48 \%$ \\
$2 / 25 / 2010$ & $-1.38 \%$ & & $4 / 30 / 2010$ & $-1.81 \%$ \\
$2 / 26 / 2010$ & $6.50 \%$ & & $5 / 3 / 2010$ & $0.48 \%$ \\
$3 / 1 / 2010$ & $-3.96 \%$ & & $5 / 4 / 2010$ & $-3.10 \%$ \\
$3 / 2 / 2010$ & $2.94 \%$ & & $5 / 5 / 2010$ & $0.21 \%$ \\
$3 / 3 / 2010$ & $1.06 \%$ & & $5 / 6 / 2010$ & $0.96 \%$ \\
$3 / 4 / 2010$ & $-2.76 \%$ & & $5 / 7 / 2010$ & $2.28 \%$ \\
$3 / 5 / 2010$ & $0.99 \%$ & & $5 / 10 / 2010$ & $-0.31 \%$ \\
$3 / 8 / 2010$ & $-1.46 \%$ & & $5 / 11 / 2010$ & $-2.87 \%$ \\
$3 / 9 / 2010$ & $-0.89 \%$ & & $5 / 12 / 2010$ & $-3.70 \%$ \\
$3 / 10 / 2010$ & $-0.34 \%$ & & $5 / 13 / 2010$ & $-1.27 \%$ \\
$3 / 1 / 2010$ & $2.77 \%$ & & &
\end{tabular}


Table 2. Daily Abnormal Returns for Volvo from 15 February 2010 to May 12, 2010 in percent

\begin{tabular}{lcccc}
\hline Date & ARt= Rt-E(Rt) & & Date & ARt= Rt-E(Rt) \\
\cline { 1 - 1 } \cline { 5 - 5 } $2 / 15 / 2010$ & $-0.55 \%$ & & $4 / 19 / 2010$ & $-0.93 \%$ \\
$2 / 16 / 2010$ & $-0.35 \%$ & & $4 / 20 / 2010$ & $-0.28 \%$ \\
$2 / 17 / 2010$ & $-1.55 \%$ & & $4 / 21 / 2010$ & $0.68 \%$ \\
$2 / 18 / 2010$ & $-0.91 \%$ & & $4 / 22 / 2010$ & $3.28 \%$ \\
$2 / 19 / 2010$ & $0.85 \%$ & & $4 / 23 / 2010$ & $6.78 \%$ \\
$2 / 22 / 2010$ & $-0.66 \%$ & & $4 / 26 / 2010$ & $3.25 \%$ \\
$2 / 23 / 2010$ & $-0.99 \%$ & & $4 / 27 / 2010$ & $-0.98 \%$ \\
$2 / 24 / 2010$ & $-0.71 \%$ & & $4 / 28 / 2010$ & $-0.92 \%$ \\
$2 / 25 / 2010$ & $0.22 \%$ & & $4 / 29 / 2010$ & $-0.29 \%$ \\
$2 / 26 / 2010$ & $-0.75 \%$ & & $4 / 30 / 2010$ & $1.61 \%$ \\
$3 / 1 / 2010$ & $0.90 \%$ & & $5 / 3 / 2010$ & $-2.01 \%$ \\
$3 / 2 / 2010$ & $2.82 \%$ & & $5 / 4 / 2010$ & $-0.71 \%$ \\
$3 / 3 / 2010$ & $-0.88 \%$ & & $5 / 5 / 2010$ & $1.60 \%$ \\
$3 / 4 / 2010$ & $-0.19 \%$ & & $5 / 6 / 2010$ & $1.75 \%$ \\
$3 / 5 / 2010$ & $0.71 \%$ & & $5 / 7 / 2010$ & $0.71 \%$ \\
$3 / 8 / 2010$ & $0.59 \%$ & & $5 / 10 / 2010$ & $-1.84 \%$ \\
$3 / 9 / 2010$ & $0.38 \%$ & & $5 / 11 / 2010$ & $0.26 \%$ \\
$3 / 10 / 2010$ & $0.75 \%$ & & $5 / 12 / 2010$ & $-1.38 \%$ \\
\hline $311 / 2010$ & $1.14 \%$ & & &
\end{tabular}

$3 / 11 / 2010$

$3 / 12 / 2010$

$3 / 15 / 2010$

$3 / 16 / 2010$

$3 / 17 / 2010$

$3 / 19 / 2010$

$3 / 22 / 2010$

$3 / 23 / 2010$

$3 / 25 / 2010$

$3 / 26 / 2010$

$3 / 29 / 2010$

$3 / 30 / 2010$

$4 / 31 / 2010$

$4 / 6 / 2010$

$4 / 7 / 2010$

$4 / 8 / 2010$

$4 / 9 / 2010$

$4 / 12 / 2010$

$4 / 14 / 2010$

$4 / 15 / 2010$

$4 / 16 / 2010$

$1.14 \%$

$1.53 \%$
$0.55 \%$

$-1.78 \%$

$0.71 \%$

$1.46 \%$

$2.72 \%$

$-0.32 \%$

.

$-1.41 \%$

$1.05 \%$

$-1.07 \%$

$-0.47 \%$

$-0.63 \%$

$0.03 \%$

$3.02 \%$

$-0.91 \%$

$0.41 \%$

$0.43 \%$

$3.98 \%$

$-1.65 \%$

$-0.07 \%$

$2.02 \%$
Table 3. Standardized Abnormal Returns and Significance Test Statistics for Geely's Stock Prices Over the Event Horizon

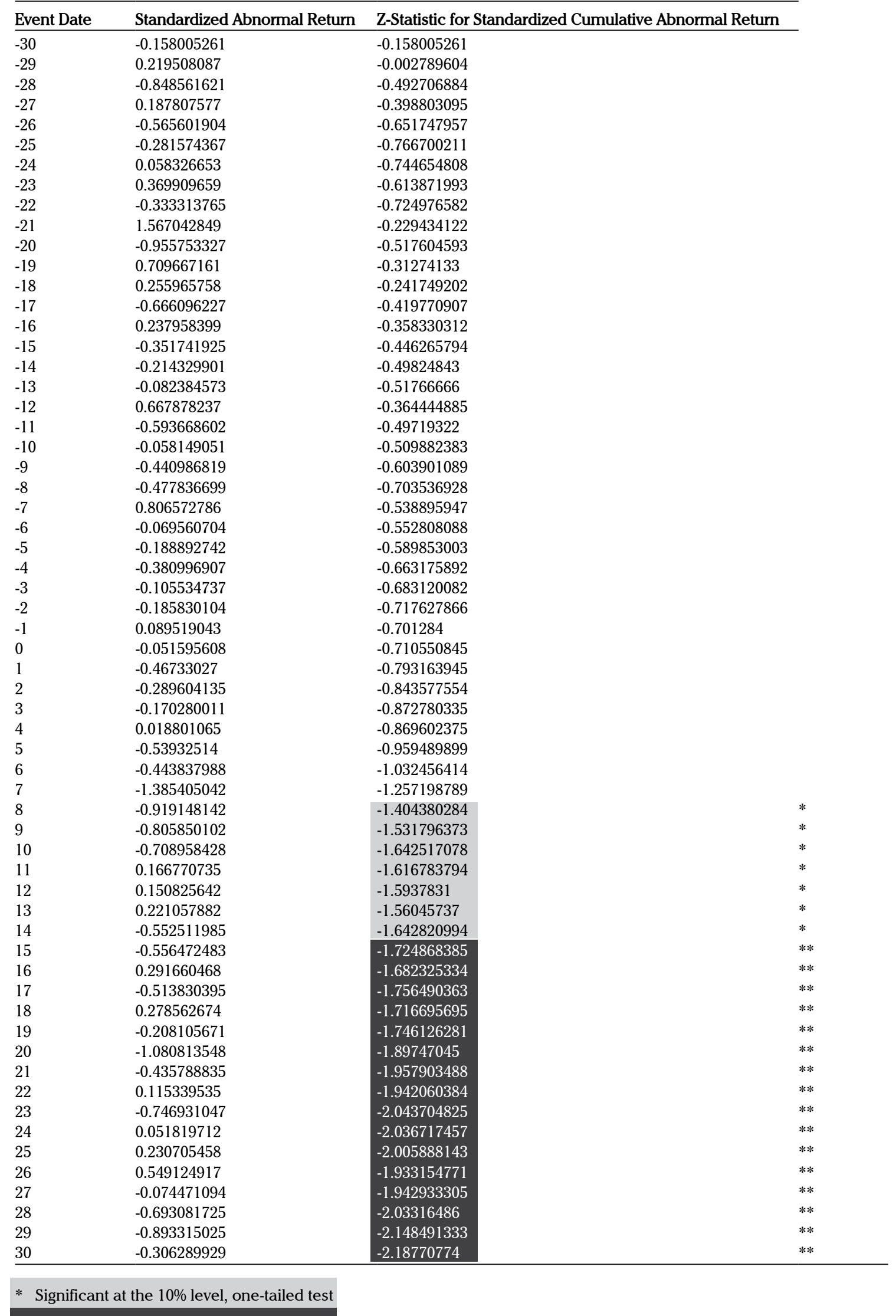

* Significant at the $10 \%$ level, one-tailed tes 
Table 4. Standardized Abnormal Returns and Significance Test Statistics for Volvo's Stock Prices Over the Event Horizon

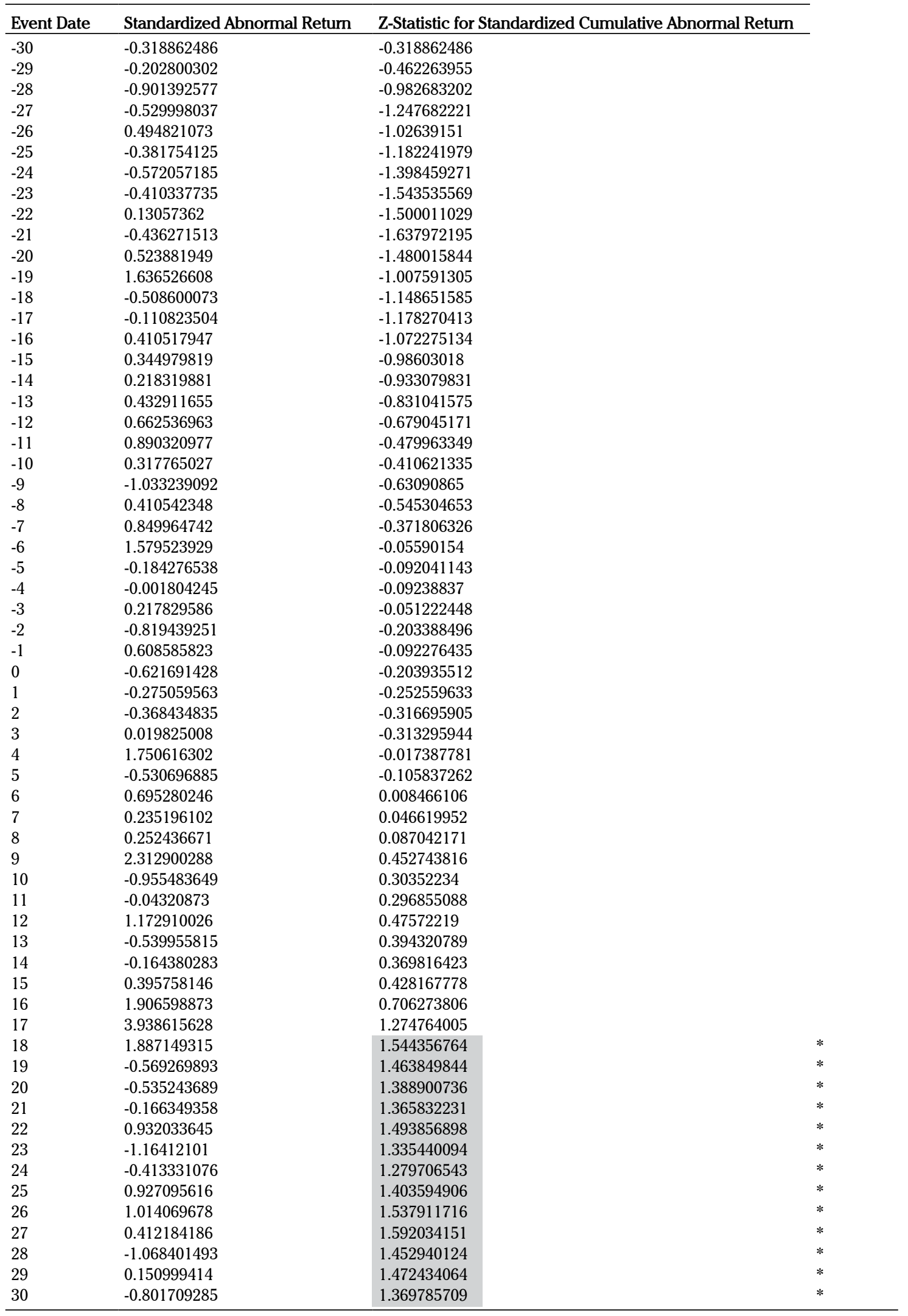

* Significant at the $10 \%$ level, one-tailed test significant negative cumulative abnormal returns. The statistical results also indicate the acquisition announcement has a significant positive impact on Volvo's shareholder cumulative return from the period of $(-30,18)$ days until the period of $(-30,30)$ days of acquisition period.

The statistical analysis by measuring ex ante market reaction, assuming semi strong-form of efficient market hypothesis holds, indicates that market perceived Geely's action as negative present value investment. On the other side, the market perceives the equity of Volvo has been increased by the merger.

\section{MANAGERIAL IMPLICATIONS}

Consistent with previous results, studies over the years have shown that most acquisitions fail to add value for shareholders in the acquiring company (Doyle, 2008). First, the bid premium paid by the acquiring company averages between 40 and 50\% over the acquired company's pre-acquisition value due to over optimistic forecasts of the market's growth potential or over estimate the synergies creating by the acquisition. The premium is lower for a friendly merger and higher for a hostile takeover.

Second, shareholders in the acquired company are the big winner, receiving the benefits of the bid premiums. In two-thirds of takeovers, the value of the acquiring company declined after the acquisition. Taking a longer run view, only around a quarter of acquisitions were judged successful in delivering satisfactory returns to shareholders. The higher the bid premium, the more likely the acquisition was to fail.

The chances of an acquisition being successful were improved when the acquirer had a strong core business before the take-over. The success rate was also higher where the company being bought was relatively small and in a related business. However, wrong plan implementation of post acquisition, improper incentive systems resulted on the high cost and eroded relationship with the customers, staff and suppliers in acquired company will damage the value of the business (Doyle, 2008)

Furthermore, merger and acquisition can sometime create problems for brands. Some unsuccessfu results are reported, such as ExxonMobil and DaimlerChrysler that confused the customer to associate the blended value from different base emotional bonding of each brand caused. The successful one empowers the strong points of both and carefully places the local concern on their consideration (Temporal, 2010).

These sources of potential synergy value include economies of scale and scope (Bradley, 1983) (Bradley M. A., 1988); efficiency of resources (Coase 1937); technology transfer (Freedman, 1989) and corporate control (Alchian, 1972). Specifically, Doyle (2008) mentioned that the main synergies might include several savings such as cost savings as a result of economies of scale, eliminatin duplicated jobs and transferring of best practices. Investment savings will be realized from economies in fixed and working capital requirement. In terms of taxes and cost of capital reduction, the combine cash tax rate and the company's weighted cost of capital will be improved. Finally, sales growth wil be enhanced through broader distribution channel.

Basically, most agree that acquisitions have certain advantages over internal growth. Acquisitions are faster way to penetrate a market. Developing successful new products can take years whereas an acquisition can achieve the sales goal in weeks. Internal growth is costly, a competitive battle to win market share can be very expensive and buying a business is less likely to cut industry margins. Some strategic assets such as well-known brands, paten and strong distribution channels are often difficult, if not impossible, to develop internally. Furthermore, an established business is typically less risky than developing a new one from scratch (Doyle,2008) 
a new global market. Using the three criteria on speed, control and investment, it benefits in fast speed and medium control but needs high investment. The trade-off between cost and benefit should be considered in choosing entry strategy by matching it up with the objectives and resource (Keller, 2008).

Merger and acquisition are sometimes intended to build stronger presence in some countries, reach economies of scale in production and distribution, lower marketing costs, communication of powe and scope, consistency in brand image, an ability to leverage good ideas quickly and efficiently, and uniformity of marketing practices and thus greater competitiveness. On the other side, the acquisition can possibly ignore the differences local needs, wants, and usage patterns, consumer response, the macro environment, marketing institution and administrative procedures (Keller 2008).

The fact that the acquisition is supported by Geely management and by Chinese government might affirm the idea that actually the optimistic level o forecast should be measured through series of time and from a much broader view including marketing and strategic management. Geely's reputation is quite high in China, but does not make strong resonance worldly.

Having noticed the above experience, Geely acted different strategic plans. Although Geely had the blueprint of Volvo development, Geely's top management decided that Volvo will be managed independently. The Volvo brand is expected to keep its unique characteristic as an unbeatable vitality and competitive strength of world-leading premium carmaker with global reputation in safety and environment-friendly technology. Geely will not produce Volvo and Volvo will not produce Geely. Thus, the damaging process on the value of the business could be avoided, because the relationship among customers, staff and supplier will remain the same.
Although current management structure would be maintained to avoid costly corporate restructuring process, the acquisition of Volvo by Geely is intended to transfer the best practice. Recall that the biggest desire of government of China in automotive industry which clearly mentioned in Automotive Industry Readjustment and Revitalization Plan is to ensure the adoption of the latest advances in technology. Geely's action is viewed as the strategic step to do this particular technology transfer. This is the frog leap to adopt Volvo's achievement on safety and avant-grade operation and create value through a new set of luxury image.

Geely would have a short cut of cutting-edge technology and luxurious image transfer. In return, Volvo had an access to huge market that includes the current international and potentially emerging China market.

In fact, besides all of the synergy expected, there are some other reasons to explain the negative value creation for Geely. The independence of Volvo to run the business as usual gives impact on the building of value creation. In this case, efficiency of sources and effort has not occurred since Volvo is still produced independently. The efficiency of skillful labor wages cannot be carried on the short term and the expenses to maintain Volvo on the expected level of quality as well as aggressive action to expand the business demand huge financial source that could be new burden for Geely.

Technology transfer as an added value for Geely will also happen gradually. Geely has to make sure that there is no resistance from Volvo to transfer the technology. The mechanism of technology transfer and the readiness of Geely to absorb the technology should be prepared in order to smooth the process. It will take a long journey for Geely to embrace the whole benefits.

The value creation will happen if the company delivers the right value to the customer. Acquisition influences the vision of Geely to Volvo's future. Geely has two choices which can be implemented on the future Volvo products, it follows the most potential market expectation on luxurious segment or looks for the way of Chinese market perception on safety. Although there is compromising between the new owner and the chief executive of Volvo, blending the different culture from two companies become the challenge to build value creation. However, the most important thing is Geely's understand ability about the expectation and perception of the Chinese potential market toward the 'new' Volvo brand and the way to express the inheritance personality of the brand into the Chinese value. Otherwise, the new potential market will see no clear benefits of the acquisition and brand resonance between the company and the consumers as an indicator of value creation is difficult to achieve (Neal \& Strauss, 2008). The company should go forward to maximize coherence and brand strategy to implement their corporate strategy (Lambkin \& Muzellec, 2010).

\section{CONCLUSION}

Event study of this research concludes that market perceives this acquisition decrease Geely's shareholders value as an acquiring company while at the same time increase value of Volvo as the acquired company. These results are generally consistent with previous event studies which state that the acquirer will show diminishing value and the target will benefit the increasing value after the acquisition.
This pessimistic result was analyzed further by considering different angle. The confusing personality of on building value creation because both brands have different targets with different values. Even studies should definitely be supplemented by thorough discussion of value synergies creation from broader perspectives which might be hard to measure solely by stock price movements such a the value of technology transfer and China marke penetration which might have been implicitly created by the acquisition of Volvo by Geely.

Data for further research might be expanded far into the future to capture a more complete picture of acquisition analysis. Since the acquisition happen recently, it might be a wise decision to wait until three or four more years to judge whether this merger is a successful one. Finally, the association of stock movement and the development of the market such as in an emerging market like Hong Kong Stock Exchange should be analyzed further In the marketing perspective, the research of consumer insight, especially from Chinese market should be conducted to sharpen the marketing strategy to be implemented in the future as the response to the unsatisfactory prediction to the future. 


\section{EFERENCES}

Alchian, A. A. (1972). Production Information Costs, and Economic Organization. American Economic Review, 62(5), 777 795.

Almeida, P. (1996). Knowledge sourcing by foreign multinationals: Patent citation analysis in the US semiconductor industry. Strategic Management Journal, 17(2), 155-165.

Andrade, G., Mitchell, M. and Stafford, E. (2001). New Evidence and Perspective On Mergers, Journal of Economic Perspectives, 15(2), 103-120.

Bhagat, S. and Hirshleifer, D.A. (1996). Do Takeover Create Value? An International Approach. Working Paper. Graduate School of Business. University of Michigan.

Black, E.L., Carnes, T.A. and Jandik, T. (2001). The Long-Term Success of Cross-Border Mergers and Acquisitions. Social Science Research Network. Retrieved from http://www.ssrn.com.

Bradley, M. A. (1983). The Rationale Behind Interfirm Tender Offers: Information or Synergy. Journal of Financial Economics, $11,183-206$.

Bradley, M. A. (1988). Synergistic Gains From Corporate Acquisitions and Their Division Between the Stockholders of Target f Financial Economics, 21, 3-40.

Brimble, P. and Sherman, J. (1999). Mergers and Acquisition in Thailand: The Changing Face of Foreign Direct Investment. Paper presented at the United Nations Conference on Trade and Development.

Campa, J.M. \& Hernando, I. (2004). Shareholder Value Creation in European M\&As. European Financial Management, 10(1), $47-81$.

Chang, S. J. (1995). International expansion strategy of Japanese firms: Capability building through sequential entry Academy of Management Journal, 38(2), 383-407.

China Association of Automobile Manufacturers. (2009). Automotives Statistics. Retrieved from http://www.caam.org.cn. Coase, R. (1937). The Nature of the Firm. Economica, 386-405.

Conn, R.L., Cosh, A., Guest, P.M. \& Hughes, A. (2005). The Impact on UK Acquirers of Domestic, Cross-border, Public and Private Acquisitions. Journal of Business Finance \& Accounting, 32(5/6), 815-870.

Copeland, T., Koller, T., and Murrin, J. (1996). Valuation: Measuring and Managing the Value of Companies. John Wiley \& Sons, Inc., New York.

Croci, E. (2005). Why Do Managers Make Serial Acquisitions? An investigation of Performance Predictability in Serial Acquisitions. Social Science Research Network. Retrieved from: http://www.ssrn.com.

Datta, D.K., Pinches, G.E. and Narayanan, V.K. (1992). Factors Influencing Wealth Creation from Mergers and Acquisitions: A Meta-analysis. Strategic Management Journal, 13(1), 67-84.

Datta, D. and Puia, G. (1995). Cross-border Acquisitions: An Examination of the Influence of Relatedness and Cultural Fit on Shareholder Value Creation in US acquiring firms, Management International Review, 35, 337-359.

Dodd, P. and Warner, J.B. (1983). On Corporate Governance: A Study of Proxy Contests. Journal of Financial Economics, $11,401-438$.

Dolan, M. \& Shirouzu. (2009). Ford agrees to terms for sale of Volvo unit. Wall Street Journal (Eastern ed.) p. B.1.

Dolan, M. \& Shirouzu. (2010). Corporate news: Geely hopes to boost Volvo globally-Car maker sees potential in and out of China; for Ford, deal ends distraction. Wall Street Journal (Eastern ed.), p. B.2

Dolley, Clay, J. (1933). «Characteristics and Procedure of Common Stock Split-Ups», Harvard Business Review, 11, 316-26.

Donnelly, T., Morris, D., Donnelly, T. (2005). Renault-Nissan: a marriage of necessity? European Business Review, 17(5), 428440.

Doyle, P. (2008). Value-Based Marketing: Marketing Strategies for Corporate Growth and Shareholder Value, 2nd ed. John Wiley \& Sons, Ltd. West Sussex, England.

Doz, Y., Santos, J., \& Williamson, P. (2001). From global to multinational: How companies win in the knowledge economy.

Fama, E., Fisher, L., Jensen, M. and Roll, R. (1969). The Adjustment of Stock Prices to New Information. International Economics Review, 10, 1-21.

Fama, E.F. (1976). Foundations of Finance: New York: Basic Books.

Freedman, R. (1989). A Theory of the Impact of International Cross-Listing. Working Paper, Standford University.

Gubbi, S.R., Aulakh, P.S., Ray, S., Sarkar, M.B., \& Chittoor, R. (2010). Do international acquisitions by emerging-economy firms create shareholder value? The case of Indian firms. Journal of International Business Studies. 41(3), 397-419,

Harris, R. and Ravenscraft, D. (1991). The Role of Acquisitions in Foreign Direct Investments: Evidence from the US Stock Market, Journal of Finance, 46(3),825-844.

Harlem, S., and Schramm, R.( 2009). The Coming Wave of Consolidation in Chinese Industries. The China Business Review,
$36(6), 50$

Hitt, M. A., Hoskisson, R. E., \& Kim, H. (1997). International diversification: Effects on innovation and firm performance in product-diversified firms. Academy of Management Journal, 40(4), 767-798.

Jensen, M.C. and Ruback, R.S. (1983). The Market for Corporate Control. Journal of Financial Economics, 11, 593-638. Jensen, M.C. (2006). Takeovers: The Controversy and the Evidence. Social Science Research Network, Retrieved from: http://www.ssrn.com.

Kang, J.K. and Takeshi, Y. (1996). The Japanese Market for Corporate Control and Managerial Incentives. Working Pape University of California, Riverside, CA.

Kang, J.K., Anil, S. and Takeshi, Y. (2000). The Effect of Bank Relations on Investment Decisions: An Investigation of Japanes Takeovers Bids. Journal of Finance, 55, 2197-2218.

Keller, K.L. (2008). Strategic Brand management. Building, Measuring, and Managing Brand Equity. New Jersey: Pearson Education. Inc.

Laabs, J. and Schiereck, D. (2010). The long-term success of M\&A in the automotive supply industry: determinants of capital market performance. Journal of Economics and Finance, 34 (1), 61-88.

ambkin, M.C. \& Muzellec,L. (2010). Leveraging brand equity in business-to-business mergers and acquisitions. Industria Marketing Management, 39,1234-1239.

Lundbäck, M., Hörte, S. (2005). Decision-making in conditions of constant change- case within the automotive industry. Management Decision, 43(2), 220-235.

MacKinlay, A.C. (1997). Event studies in economics and finance. Journal of Economic Literature, 35(1),13-39.

Makino, S., Lau, C. M., \& Yeh, R. S. (2002). Asset-exploitation versus asset-seeking: Implications for location choice of foreig direct investment from newly industrialized economies. Journal of International Business Studies, 33(3), 403-422.

McWilliams, A \& Siegel, D. (1997). Event studies in management research: Theoretical and empirical issues. Academy of Management Journal, 40(3), 626-657.

Moeller, S.B., \& Schlingemann, F.P. (2005). Global diversification and bidder gains: A comparison between cross-border and domestic acquisitions. Journal of Banking and Finance, 29(3), 533-564

Pettway, R.H. \& Yamada, T. (1986). Mergers in Japan and their Impacts upon Stockholders' Wealth. Financial Management, 15(4), 43.

Reuer, J.J., Shenkar, O., \& Ragozzino, R. (2004). Mitigating risk in international mergers and acquisitions: The role of contingent payouts. Journal of International Business Studies, 35(1), 19-32

Seth, A., Song, K.P., \& Pettit, R. R. (2002). Value creation and destruction in cross-border acquisitions: An empirical analysis .

Shan, W., \& Song, J. (1997). Foreign direct investment and the sourcing of technological advantage: Evidence from the biotechnology industry. Journal of International Business Studies, 28(2), 267-284.

Shimizu, K., Hitt, M.A., Vaiyanath, D., \& Pisano, V. (2004). Theoretical foundations of cross border mergers and acquisitions A review of current research and recommendations for the future. Journal of International Management, 10(3), 307

Songswang, A. (2010). M\&A for Value Creation: The Experience in Thailand. Journal of Contemporary Research In $1(11), 28-50$

Temporal, P. (2010). Advanced Brand Management Managing Brands in A Changing World. Singapore: John Wiley and Sons (Asia) Pte. Ltd.

Tuch, C., \& O'Sullivan, N. (2007). The impact of acquisitions on firm performance: A review of the evidence. International 作,

Uhlenbruck, K., Hitt, M. A., \& Semadeni, M. (2006). Market value effects of acquisitions involving Internet firms: A resource based analysis. Strategic Management Journal, 27(10), 899-913.

Vu, D.A, Shi, Y. and Hanby, T. (2009). Strategic framework for brand integration in horizontal mergers and acquisitions. Journal of Technology Management in China. Bradford 4 (1), 26. 